\title{
SYBILLA DAKOVIĆ
}

Uniwersytet Wrocławski

Wrocław, Polska

\section{Polskie ekwiwalenty przekładowe chorwackiego przyimka unatoč}

Chorwacki przyimek koncesywny unatoč należy do prepozycji bardzo rzadkich. W informacjach, jakie pojawiają się w chorwackiej literaturze fachowej, napotkać można wiele nieścisłości dotyczących przede wszystkim jego pochodzenia oraz łączenia się przyimka $\mathrm{z}$ danym przypadkiem. $Z$ jednej strony kwestia jego etymologii jest rzadko poruszana, z drugiej — występujące w nielicznych źródłach informacje są sprzeczne. Hrvatska gramatika ${ }^{1}$ sytuuje przyimek unatoč w kategorii przyimków pierwotnych (pravi, primarni prijedlog), zaś elektroniczny słownik Hrvatski jezični portal sugeruje jego pochodzenie od rzeczownika tok lub czasownika teći oraz przimków $u$ oraz $n a\left(, \mathrm{u}-+v \cdot\right.$ na $+v$. tok, teći” $\left.{ }^{2}\right)$. Forma unatoč może pełnić także funkcję przysłówkową, co nie jest jednak odnotowywane przez wszystkie źródła leksykograficzne ${ }^{3}$.

Przedmiotem sporu w literaturze specjalistycznej jest też łączliwość przyimka unatoč, którą często rozpatruje się w kontekście normy językowej. Rozważa się tu występowanie przyimka z celownikiem lub dopełniaczem. Poradniki językowe, lecz także niektóre gramatyki i słowniki, opowiadają się za stanowiskiem, że jedynym poprawnym połączeniem jest połączenie $z$ celownikiem ${ }^{4}$. Prace, które

${ }^{1}$ E. Barić et al., Hrvatska gramatika, Zagreb 1997, s. 278.

2 http://hjp.znanje.hr (dostęp: 13.04.2016).

${ }^{3}$ Nie odnotowuje tego Rječnik hrvatskoga jezika, red. J. Šonje, Zagreb 2000. Co więcej, w gramatyce z końca XIX wieku T. Maretić wspomina o dominującym użyciu tej formy w funkcji przysłówka, a sporadycznie jako przyimka (idem, Gramatika i stilistika hrvatskoga ili srpskoga književnog jezika, Zagreb 1899, s. 488, 551), zaś obecne źródła (np. V. Anić, Rječnik hrvatskog jezi$k a$, Zagreb 1998) unatoč określają jako przyimek z możliwym użyciem przysłówkowym w jednym z dwóch znaczeń.

${ }^{4}$ Zob. N. Opačić, Reci mi to kratko i jasno, Zagreb 2009; A. Frančić, M. Mihaljević, L. Hudeček, Normativnost $i$ višefunkcionalnost u hrvatskome standardnom jeziku, Zagreb 2005; 
sankcjonują łączliwość zarówno z celownikiem, jak i dopełniaczem, należą do nielicznych. Niektóre informują o tym w sposób niebezpośredni, np. gramatyka Josipa Silicia i Ivo Pranjkovicia, w której równolegle ze stwierdzeniem, że unatoč należy do przyimków, które ,primarno dolaze s dativom (to je u skladu i s normativnim preporukama)" ${ }^{5}$, opis jego znaczenia podawany jest w rozdziale o dopełniaczu ${ }^{6}$. Trudno jest tu jednoznacznie stwierdzić, czy autorzy są skłonni uznać normę językową, czy ją podważają, szczególnie że w innym miejscu piszą o tendencji przejmowania przez dopełniacz przyimków celownikowych i dążenia celownika chorwackiego do analityzmu ${ }^{7}$ czy o zmianie przypadka na dopełniacz w stylu urzędowym ${ }^{8}$.

Przyimek ten w podobny sposób, to znaczy w rozdziałach dotyczących i dopełniacza, i celownika, omawiają Branimir Belaj i Goran Tanacković-Faletar, lecz jednocześnie w przypisie zamieszczają informację o tym, że użycia z dopełniaczem dotyczą prawie wyłącznie stylu potocznego ${ }^{9}$, co z kolei nie pokrywa się z przytoczonym twierdzeniem Silicia i Pranjkovicia.

O tendencji do zastosowania dopełniacza z przyimkiem unatoč, szczególnie w stylu potocznym, wspomina również Vlasta Rišner, a połączenie celownikowe nazywa ugruntowanym tradycją ${ }^{10}$. Wskazuje też na postpozycyjne użycie tego przyimka, właśnie z celownikiem ${ }^{11}$.

Znaczenie przyimka unatoč jest wąskie, wyspecjalizowane. Najczęściej stosowana jest tu etykieta znaczenie przyzwolenia (dopusno značenje), którą uszczegóławiają definicje: ,kad se konstatira da nešto biva, postoji i sl. iako nije suglasno s okolnošću izloženom u padežnom izrazu s ovim prijedlogom”12 czy „protivno onomu što se suprotstavlja, odupire, onomu koji je protiv, usprkos"13.

Najczęstsza funkcja składniowa, w jakiej występuje wyraz unatoč, to funkcja okolicznika przyzwolenia (priložna oznaka dopuštanja), np. „Nastavili su s poslom unatoč nevremenu". J. Silić i I. Pranjković wymieniają ponadto występowanie przy-

Rječnik hrvatskoga jezika...; E. Barić et al., Hrvatska gramatika, Zagreb 1997; D. Raguž, Praktična hrvatska gramatika, Zagreb 1997; S. Babić, B. Finka, M. Moguš, Hrvatski pravopis, Zagreb 1994; S. Pavešić, V. Barac-Grum, Jezični savjetnik s gramatikom, Zagreb 1971; L. Jonke, Književni jezik u teoriji i praksi, Zagreb 1965; T. Maretić, Gramatika i stilistika hrvatskoga ili srpskoga književnog jezika, Zagreb 1899.

5 J. Silić, I. Pranjković, Gramatika hrvatskoga jezika, Zagreb 2007, s. 222.

${ }^{6}$ Ibidem, s. 218.

${ }^{7}$ Ibidem, s. 221, 244.

${ }^{8}$ Ibidem, s. 381.

${ }^{9}$ B. Belaj, G. Tanacković-Faletar, Kognitivna gramatika hrvatskoga jezika. Knjiga prva: Imenska sintagma i sintaksa padeža, Zagreb 2014, s. 358.

10 V. Rišner, Unatoč tome, tomu i toga, http://radio.hrt.hr/ep/unatoc-tome-tomu-i-toga/142292/ (dostęp: 11.03.2016).

${ }^{11}$ Użycie postpozycyjne autorzy Hrvatstke gramatike wiążą z zaakcentowaniem relacji

(E. Barić et al., op. cit., s. 598).

12 Unatoč, [hasło w:] Hrvatski jezični portal, http://hjp.znanje.hr (dostęp: 13.04.2016).

13 Unatoč, [hasło w:] Rječnik hrvatskoga jezika, s. 1307. 
imka w połączeniu z zaimkiem tome, tomu, nazywając taki ciąg priložna oznaka zamjeničkog tipa, czyli okolicznik typu zaimkowego ${ }^{14}$. Takie połączenie, według autorów, może także pełnić funkcję spójnika na poziomie tekstu (konektor), np. „Za ispit iz matematike spremao se tri mjeseca. Unatoč tomu izgubio bi godinu". Inny ciąg zawierający badany przyimek - unatoč tome što - wprowadza podrzędne zdanie okolicznikowe przyzwolenia (priložna/adverbijalna rečenica; uzročnodopusna rečenica $)^{15}$, np. „Razgovaraju unatoč tome što su se posvađali”.

Zadaniem, jakie stawiamy sobie w tej pracy, jest ustalenie zasobu polskich ekwiwalentów chorwackiego przyimka unatoč w oparciu o chorwacki korpus współczesnych tekstów literackich ${ }^{16}$ oraz ich polskich przekładów różnych tłumaczy. Zastosowana metoda konfrontatywna przy doborze odpowiednio szerokiego korpusu umożliwia ponadto przedstawienie relacji ilościowych pomiędzy poszczególnymi odpowiednikami, co może być wskaźnikiem dla bliższej lub dalszej ekwiwalencji. Badaniu poddane zostanie także prawostronne otoczenie przyimka; podjęta będzie też próba odpowiedzi na pytanie o jego wpływ na użycie danego ekwiwalentu.

Dane dotyczące frekwencji okazały się istotne już na etapie ekscerpowania materiału wyjściowego, potwierdziły bowiem przytoczoną na początku pracy informację o rzadkim występowaniu przyimka unatoč w stylu literackim. Otóż z 34 pozycji literackich, stanowiących wstępny korpus tekstów, w większości powieści, do docelowego korpusu weszło tylko 15 dzieł, gdyż tylko w tylu wystąpił badany przyimek. Analizie ostatecznie poddano 96 zdań, przy czym pod uwagę nie były brane te formy unatoč, które wchodzą w skład spójnika wprowadzającego zdanie okolicznikowe przyzwolenia.

Ekscerpcja materiału chorwackiego pozwoliła także ustosunkować się do wspomnianego problemu normatywnego, to jest użyć przyimka unatoč z celownikiem bądź dopełniaczem. W badanym materiale pojawiły się jedynie dwa użycia $\mathrm{z}$ dopełniaczem ${ }^{17}$, a zdecydowaną większość stanowiły połączenia celownikowe, występujące również $\mathrm{u}$ autora, który zastosował połączenie $\mathrm{z}$ dopełniaczem.

Otoczenie prawostronne przyimka unatoč nie było dotąd przedmiotem badań. Na podstawie zgromadzonego materiału można stwierdzić, że znajdują się w nim zarówno rzeczowniki abstrakcyjne, jak i konkretne, lecz zdecydowanie przeważają pierwsze z nich. Rzeczowniki abstrakcyjne nazywają ludzkie uczucia (zwykle negatywne), postawy, stany usmysłu, wiedzę, na przykład: unatoč gorčini, olakšanju, ne-

14 J. Silić, I. Pranjković, op. cit., s. 308, 362.

15 Ibidem, s. 350.

${ }^{16}$ Wśród źródeł ekscerpcji znalazły się dzieła autora, który nie urodził się w Chorwacji, lecz w Czarnogórze, ale osiadł i tworzył w Chorwacji — mowa tu o Mirku Kovaču. Jego dzieła zaliczane są do kanonu nie tylko literatury chorwackiej, a za umieszczeniem jego prac w materiale źródłowym i uznaniem jego idiolektu za język chorwacki przemówiła obecność jego twórczości w korpusie języka chorwackiego Hrvatska jezična riznica stworzonego przez Institut za hrvatski jezik i jezikoslovlje.

${ }^{17}$ Dotyczy to dzieła M. Kovača, Vrata od utrobe. 
zadovoljstvu, požudi, gadnim predosjećanjima, lažnim dojmovima, svojoj emancipaciji, iskustvu), sporadycznie odczucia i stany fizyczne czy fizjologiczne, na przykład: unatoč bolu, zadihanosti, svojim visokim godinama, fetusno-uterusnim procesima. Prawostronne otoczenie stanowią także rzeczowniki lub grupy imienne oznaczające zjawiska niezależne od człowieka, zewnętrzne, na przykład o charakterze meteorologicznym: unatoč buri, sparini, vrućini, nepovoljnim biometeoroškim prilikama, albo takie, które stanowią skutek działań ludzi lub pewnych sił czy nazywają same działania: unatoč tim nedaćama, strijeljanima, vješanjima, konfiskacijama, robijanju, borbenoj grmljavini i pjenušanju gliserovih propelerčića, vrtoglavom i mahnitom protjecanju bića, općoj katastrofi, uočenim prazninama u izlaganju, verbalnim podrškama ženskih prava, popularnosti manekenskih mršavica, direktorovom glasu, pomnom ispitivanju, obećanju, svojim moralističkim naporima. Znaczną część $\mathrm{z}$ nich reprezentowały rzeczowniki odczasownikowe.

Rzeczowniki konkretne nieżywotne występują w bardzo ograniczonej liczbie i nazywają przeważnie element odzieży lub jej detal, biżuterię bądź zapach: unatoč uniformi, najmodernijoj sportskoj košulji, dubokim ovalnim izrezima njenih širokih pletenih bluza, parfemu Caron, bogatom zlatnom nakitu oraz części ciała: unatoč urokljivih očiju. Ponadto wystąpił rzeczownik konkretny kapi w odniesieniu do deszczu oraz dwa pojęcia geograficzne: tjesnac oraz gorski lanci.

Rzeczowniki żywotne stanowiły pojedyncze użycia: unatoč svojim prijateljima studentima ljevičarima, zaštitniku, jednak szerszy kontekst ujawniał, że przeszkodę w realizacji działania nie stanowią same osoby, lecz pewien zespół cech lub działań z nimi związanych.

Prawostronne otoczenie przyimka stanowiły też zaimki: uogólniający unatoč svemu oraz wskazujący unatoč tomu/tome.

W języku polskim relację przyzwolenia według Marii Lesz-Duk ${ }^{18}$ komunikuje siedem wyrażeń przyimkowych: mimo $+\mathrm{D}$, pomimo $+\mathrm{D}$, wbrew $+\mathrm{C}, n a$ przekór $+\mathrm{C}$, przeciw $+\mathrm{C}$, przeciwko $+\mathrm{C}$, bez względu na $+\mathrm{B}$, z kolei Beata Milewska ${ }^{19}$ wymienia ich pięć, z których tylko jedno: niezależnie od + D nie zostało ujęte w spisie M. Lesz-Duk. W badanym materiale jako ekwiwalenty przyimka unatoč wystąpiły cztery spośród powyższych wyrażeń przyimkowych, przy czym ich występowanie było zróżnicowane. Najczęściej odnotowywany był przyimek mimo $+\mathrm{D}-56$ użyć, ponad trzy razy rzadziej pojawiał się przyimek wbrew $+\mathrm{C}$ - 17, pomimo + D zastosowano 10 razy, zaś na przekór $+\mathrm{C}-7$. Tłumacze sięgnęli ponadto po inne niż przyimki wtórne środki, mianowicie po wyrażenie nie zwracając uwagi na $+\mathrm{A}(1)$ oraz zdania koncesywne wprowadzone przez spójniki chociaż (4) i choć $(1)^{20}$.

18 M. Lesz-Duk, Przyimki wtórne w języku polskim, Częstochowa 2011, s. 129.

19 B. Milewska, Przyimki wtórne we współczesnej polszczyźnie, Gdańsk 2003, s. 134-135.

${ }^{20}$ Jak pisze Grochowski: „Rozróżnienie: okolicznik przyzwolenia — zdanie przyzwolone jest z punktu widzenia semantycznego problemem pozornym, wynika jedynie z tradycyjnych, konwencjonalnych rozróżnień formalnych: część zdania — zdanie, zdanie proste — zdanie złożone" (idem, 
Przejdźmy teraz do omówienia konkurencyjności ekwiwalentów przyimkowych przez odwołanie się do ich charakterystyki oraz ustalenie ewentualnych ograniczeń, jeśli chodzi o prawostronne otoczenie.

\section{Unatoč $+\mathrm{C} \rightarrow \operatorname{mimo}+\mathrm{D}$}

Ekwiwalent mimo + D zdecydowanie dominował wśród wszystkich odpowiedników, stanowiąc aż 58\% zastosowań. Pochodzi on od przysłówka mimo w znaczeniu 'obok' i wyraża okoliczność przyzwolenia, to jest rozbieżność między tym, co się dzieje, a tym, czego należałoby się spodziewać. Prawostronne otoczenie ogranicza się do rzeczowników nieżywotnych, często abstrakcyjnych ${ }^{21}$. Wchodzi ponadto w skład ustalonych związków wyrazowych, na przykład mimo woli - 'bezwiednie odruchowo', mimo to $(+\mathrm{B})$, mimo wszystko $(+\mathrm{B})$ - 'wbrew okolicznościom, jednak', oraz funkcjonuje jako komponent analitycznych spójników mimo że, mimo iż, mimo to ${ }^{22}$.

Ten polski ekwiwalent został zastosowany ze wszystkimi wymienionymi wcześniej semantycznymi typami grup imiennych chorwackiego przyimka unatoč, nazywającymi na przykład:

— zjawiska atmosferyczne: ,Ja opet zovem zovem zovem unatoč nepovoljnim biometeorološkim prilikama...” — „Znowu dzwonię dzwonię dzwonię mimo niekorzystnych warunków biometeorologicznych..." (I.S. - R);

— działania: „u slučaju da ostanem tvrdoglav, odbijajući taj pretjerani kompromis sa savješću, sukobio bih se s neprobojnim i neobilaznim zidom, branom što odbija svaku logiku unatoč srdačnom pozivanju na drugarsku razmjenu mišljenja...” — „w przypadku, gdybym się nadal upierał, odrzucając ten przesadny kompromis z sumieniem, zderzyłbym się ze ścianą nie do obejścia i nie do przebycia, z zaporą przeciw wszelkiej logice, mimo serdecznego wzywania do przyjacielskiej wymiany poglądów..." (K.Š. - V);

— uczucia: „Koračao je uz bolnicu lako i zadovoljno unatoč gorčini...”— —, „Kroczył obok szpitala lekko i z zadowoleniem, mimo rozgoryczenia...” (K.Š. - - V);

- ubiór: „Ferenc je dobar tip unatoč uniformi i voli činiti dobra djela...” — „Ferenc to jest dobry chłopak, mimo munduru, i lubi robić dobre uczynki..." (K.Š $-\mathrm{V})$.

Przyimek mimo znalazł się wśród ekwiwalentów chorwackich wyrażeń przyimkowych z rzeczownikami osobowymi, jednak w thumaczeniach nastąpiło roz-

O strukturze semantycznej przyzwolenia, [w:] Semantyka tekstu i języka, red. R. Mayenowa, Wrocław 1976, s. 226). Zdania z wykładnikiem przyzwolenia choć przez Klemensiewicza zaliczane są do osobliwych okoliczników przyzwolenia (idem, Zarys składni polskiej, Warszawa 1953, s. 35), autor nie określa jednak precyzyjnie rodzaju składnika występującego po tym wykładniku, wskazując na możliwość uznania go za oznajmienie eliptyczne.

${ }^{21}$ M. Lesz-Duk, op. cit., s. 39, 129.

22 B. Milewska, Stownik polskich przyimków wtórnych, Gdańsk 2003, s. 37-38. 
szerzenie treści o cechę lub działanie, z jaką związana jest osoba. Tym sposobem w dopełniaczu przyimka mimo znalazł się rzeczownik nieżywotny, na przykład: „On je unatoč svojim prjateljima studentima-ljevičarima [...] odan velikom Generalu i stoljetnoj slavi Francuske republike” — „Mimo przyjaźni z lewicowymi studentami [...] jest on szczerze oddany wielkiemu generałowi i wielkiej sławie Republiki Francuskiej” (K.Š. - V).

\section{Unatoč $+\mathrm{C} \rightarrow$ wbrew $+\mathrm{C}$}

Kolejny pod względem frekwencji ekwiwalent to przyimek wtórny wbrew $+\mathrm{C}$ (w ustalonych konstrukcjach $+\mathrm{B})-17$ wystąpień, około $18 \%-$ pochodzący od wyrażenia przyimkowego $w+$ brew - 'oko w oko, naprzeciw'. Jest on wykładnikiem funkcji przyczynowej przyzwolenia i wskazuje na przeciwstawną okoliczność, jednak niektóre, sporadyczne użycia, które są silnie uwarunkowane kontekstowo, dotyczą funkcji warunkowej, a użycie z zaimkiem zwrotnym sobie można zaliczyć do relacji sposobu ${ }^{23}$. Uniwersalny słownik języka polskiego podaje dodatkowo informację o aspekcie wolitywnym koncesywności: „wbrew komunikuje, że dana osoba nie chciała, by się zdarzyło to, o czym jest mowa"24.

Po przyimku występują rzeczowniki bez ograniczeń, najczęściej nieżywotne ${ }^{25}$.

W grupie tej, ponad trzykrotnie mniejszej od poprzedniej, zaobserwowano mniej klas semantycznych rzeczowników poprzyimkowych, co może być związane nie tyle z faktycznymi ograniczeniami w łączliwości wpływającymi na przekład, lecz z mniejszą ilością materiału badawczego. W grupie znaczeń, które się nie pojawiły w zestawie ekwiwalentu wbrew, znalazły się nazwy stanów pogody, osób lub uczuć i stanów fizycznych. Poprzyimkowe grupy imienne oznaczają różnorodne działania oraz procesy i często są przykładem nominalizacji morfologicznej $^{26}$, na przykład: „Unatoč pomnom ispitivanju na Beatrixinom tijelu nisam otkrio nikakve značajnije mane” — „Wbrew uważnym obserwacjom nie odkryłem zresztą na jej ciele żadnej wady” (K.Š. — V); „One se djevojke odrekao vrlo lako i bez ikakve duševne krize, a stari ga je, unatoč obećanju, ipak nadigrao" — „Wyparł się dziewczyny bardzo łatwo, bez najmniejszego załamania, a stary, wbrew obietnicom, jednak wystawił go do wiatru" (K.Š. - N).

\section{Unatoč $+\mathrm{C} \rightarrow$ pomimo $+\mathrm{D}$}

Trzecim pod względem częstości odpowiednikiem jest przyimek wtórny pomimo + D (10 użyć, frekwencja około 10\%), uważany za formę pochodną od przy-

23 Ibidem, s. 100-101.

24 Wbrew, [hasło w:] Uniwersalny słownik języka polskiego, Warszawa 2004, CD-ROM.

${ }^{25}$ M. Lesz-Duk, op. cit., s. 130.

${ }^{26}$ Por. Z. Topolińska, Składnia grupy imiennej, [w:] Gramatyka wspótczesnego języka polskiego. Sktadnia, red. Z. Topolińska, Warszawa [1984], s. 354. 
imka mimo, rozszerzonego o przedrostek po-, który — według B. Milewskiej — może mieć dodatkowe znaczenie wzmacniające relację przyczynową ${ }^{27}$. Autorka określa funkcjonowanie przyimków mimo i pomimo jako identyczne i wymienne, chociaż forma pomimo jest rzadsza.

Także w tej grupie nazwy czynności i stanów przeważały w poprzyimkowej grupie imiennej. Znalazły się tu także nazwy stanów atmosferycznych: „Bio je $\mathrm{u}$ istom gradskom odijelu, bezbojnom i bezobličnom, kao i jučer, unatoč vrućini, u sivoj košulji bez kravate” — „Pomimo upału miał na sobie ten sam wczorajszy bezbarwny garnitur oraz popielatą koszulę bez krawatu" (A.Š. - L); czy — podobnie jak w wypadku ekwiwalentu mimo — nazwy odczuć fizycznych i uczuć: „posve precizno do u najmanju sitnicu osjetio sam (stanovita oštrina percipiranja unatoč mome bolu) kako tišina nije ustuknula pred napuklom zvonjavom reskog zvuka kositrenog zvona...” — „odczułem najdokładniej, w najmniejszym szczególe (jakaś ostrość percepcji, pomimo bólu), że nie cofnęła się przed drżącym, cierpkim dźwiękiem cynowego dzwonu...” (K.Š. - V); „Unatoč subjektivnom nezadovoljstvu i neostvarenim ciljevima moći ću se ovim putovanjem i boravkom u Parizu pohvaliti pred prijateljima kojima nije uspio takav pothvat” — „Pomimo niezadowolenia z niezrealizowanych planów będę mógł się tą podróżą i pobytem w Paryżu chwalić przed przyjaciółmi, którym takie przedsięwzięcie nie wypaliło" (K.Š. — V).

\section{Unatoč $+\mathrm{C} \rightarrow$ na przekór $+\mathrm{C}$}

Kolejnym ekwiwalentem, niewiele rzadszym od wspomnianego pomimo, gdyż odnotowanym 7 razy (około 7\%), był przyimek wtórny na przekór + C. Powstał on z połączenia przyimka pierwotnego $\mathrm{na}$ z postacią biernika liczby pojedynczej dawnego rzeczownika przekór - 'przekora'. Definiowany jest jako wykładnik relacji kontraryjnej, wskazując na działanie przeciwne czyjejś woli lub okolicznościom, i uważany za synonimiczny do przyimka $w_{b r e w}{ }^{28}$. Jako bliskoznaczny temu przyimkowi wymienia go także Uniwersalny słownik języka polskiego, zaznaczając jednak w definicji jednego ze znaczeń element niezgodności z czyjąś wolą ${ }^{29}$. Podobną definicję zawiera Wspótczesny stownik języka polskiego, wzbogacający znaczenie przyimka o element celowości podejmowanych działań: „,wskazuje na celowe działanie niezgodne z czyjąś wolą, życzeniami lub okolicznościami; na złość komuś" ${ }^{30}$.

M. Lesz-Duk zaznacza brak ograniczeń w pozycji rzeczownika w celowniku ${ }^{31}$.

Niewielka liczba przykładów ogranicza możliwości przedstawienia wyczerpującej analizy prawostronnej przyimka, niemniej na podstawie obecnego mate-

27 B. Milewska, Stownik polskich przyimków..., s. 84.

${ }^{28}$ Ibidem, s. 51; M. Lesz-Duk, op. cit., s. 130.

${ }^{29}$ Na przekór, [hasło w:] Uniwersalny stownik...

${ }^{30}$ Na przekór, [hasło w:] B. Dunaj, Współczesny słownik języka polskiego, Warszawa 2007, CD-ROM.

31 M. Lesz-Duk, op. cit., s. 130. 
riału można zaobserwować różnorodne pod względem znaczenia grupy imienne, włączając w nie rzeczowniki konkretne, oznaczające dosłowną fizyczną przeszkodę, która została pokonana: „Na drugom mjestu, unatoč gorskim lancima i drugim preprekama, pojavi se opet mediteranski element, mijenjajući i zemlju, i običaje, i same ljude” — „Gdzie indziej, na przekór łańcuchom górskim i różnym przeszkodom, znowu pojawia się ten czy inny element śródziemnomorski, odmieniając ziemię, obyczaje i samych ludzi” (P.M. - B).

Dalej przeszkodę stanowią procesy fizjologiczne czy cechy specyficzne człowieka, takie jak ton głosu czy „złe” spojrzenie: „To, što na neki stanovit način žudi za muzom, unatoč svim onim fetusno-uterusnim procesima, glupavo, daleko i čudno, to je dobro, zadovoljan je time...” — „To dobrze, że w pewien sposób

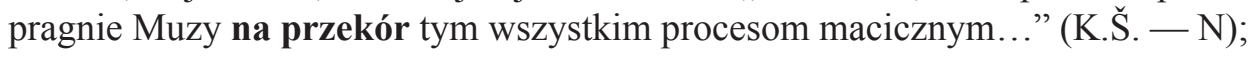
„Unatoč $[\ldots]$ tom direktorovom glasu s očitim prizvukom neređenja i zvukovima koje nije slušao, nije ih uopće slijedio u mislima, ali je njihovu važost i značenje potvrđivao klimanjem glave i osmijehom odobravanja, njegova hirovita misao vraća mu se ženama iz njegove prošlosti” — „na przekór wyraźnie rozkazującemu głosowi dyrektora - którego słów nie słuchał i w ogóle nie przyjmował do wiadomości, ale ich ważność i znaczenie potwierdzał kiwaniem głową i aprobującym uśmiechem — jego kapryśna myśl wracała do kobiet z przeszłości” (A.Š. — N); „Rosa je začela i, unatoč urokljivih očiju [+ D] (fana göz), sretno iznijela trudnoću...” - „Rosa zaszła w ciążę i na przekór rzucającym urok oczom szczęśliwie zniosła brzemienność..." (M.K. - V).

$\mathrm{W}$ ostatnim przypadku thumaczenie akcentuje działanie, jakie związane jest z rzeczownikiem poprzyimkowym, czyli rzucaniem uroku spojrzeniem.

Ponadto znajdują się tam rzeczowniki o znaczeniu ogólnie sformułowanych obecnych lub byłych zdarzeń lub sądów: na przekór niewątpliwej prawdzie, faktom, wszystkiemu.

\section{Unatoč $+\mathrm{C} \rightarrow$ nie zwracają uwagi na $+\mathrm{B}$}

W badanym materiale thumacz jako odpowiednika chorwackiego unatoč użył również wyrażenia nie zwracając uwagi na $+\mathrm{B}$ (1), zastępując formę przyimka bliskoznacznym równoważnikiem zdania. Jest to użycie odosobnione, jednak warto wymienić je jako jeden ze sposobów thumaczenia oryginalnego przyimka: „Jedan od maladića izvadio je iz fiće jarkocrvenu loptu, i ubrzo se sve četvoro sjurilo u more, unatoč hladnoći skakućući po plitkoj vodi...”- - Jeden z chłopców wyciągnął z wnętrza jaskrawoczerwoną piłkę $i$ wkrótce cała czwórka, nie zwracając uwagi na zimno, znalazła się w morzu, skacząc po płytkiej wodzie..." (A.ŠS. - L). 


\title{
Podsumowanie
}

Z przeprowadzonego badania można wyciągnąć kilka wniosków. Jeden z nich dotyczy repartycji ilościowej odpowiedników chorwackiego przyimka unatoč. Biorąc pod uwagę wartość semantyczną oraz frekwencję, za podstawowy odpowiednik tłumaczeniowy chorwackiego unatoč należy uznać polski przyimek wtórny mimo. Jego synonimiczny derywat pomimo występował już blisko sześć razy rzadziej, co może wynikać z jego rzadszego stosowania w języku polskim.

Wybór przyimka mimo przez thumaczy był dokonywany wbrew ograniczeniom łączliwości prawostronnej do rzeczowników nieżywotnych (przypominamy, że odpowiedniki wbrew oraz na przekór takich ograniczeń nie miały). Ograniczenia te były przez nich „obchodzone” przez skonkretyzowanie, uszczegółowienie znaczenia grupy imiennej za pomocą wprowadzenia semu związanego z czynnością.

$\mathrm{Z}$ kolei łączone $\mathrm{z}$ celownikiem odpowiedniki wbrew oraz na przekór uznawane za synonimy stanowiły mniej liczne (wbrew) i nieliczne (na przekór) użycia, zaś ich otoczenie prawostronne $\mathrm{w}$ badanym materiale było ograniczone do kilku klas semantycznych, co — być może — związane było z ilością zgromadzonych w grupach zdań. Znaczenie obu, jak twierdzą źródła leksykograficzne, może być rozszerzone ponadto o aspekt woli osoby przeciwdziałającej jakiemuś zdarzeniu lub okoliczności, co mocniej zaakcentowane jest w przyimku na przekór (element celowości działań). Te właśnie dodatkowe znaczenia mogły mieć wpływ na wybór przez thumacza przyimka na przekór oraz wbrew zamiast bardziej uniwersalnego mimo.

\section{Wykaz skrótów}

\author{
A. ̌́. - L - Antun Šoljan, Luka \\ A.Š. - N - Antun Šoljan, Neprilike s muzom \\ I.S. - R - Ivana Sajko, Rio Bar \\ K.Š. - - V - Krsto Špoljar, Vrijeme i paučina \\ K.Š. - N - Krsto Špoljar, Neprilike s muzom \\ M.K. - V - Mirko Kovač, Vrata od utrobe \\ P.M. - B - Predrag Matvejević, Mediteranski brevijar
}

\section{Bibliografia}

\section{Źródła}

Bagić K., Goli grad, Naklada MD, Zagreb 2003.

Bagić K., Nagie miasto, tłum. grupowe, Wydawnictwo Uniwersytetu Ślaskiego, Katowice 2009.

Horvat J., ,, Besa”- dziennik podróży, przeł. J. Knabe, Wydawnictwo Morskie, Gdańsk 1981.

Horvat J., Besa I, Neretva, Zagreb 2005.

Kovač M., Drzwi żywota, przeł. G. Łatuszyński, Wydawnictwo Łódzkie, Łódź 1988. 
Kovač M., Grad u zrcalu, Fraktura, Zaprešić 2007.

Kovač M., Kristalne rešetke, Fraktura, Zaprešić 2004.

Kovač M., Krystaliczna sieć, przeł. D. Jovanka Ćirlić, Fundacja Pogranicze, Sejny 2006.

Kovač M., Miasto w lustrze, przeł. D. Jovanka Ćirlić, Pogranicze, Sejny 2012.

Kovač M., Vrata od utrobe, Večernji list, Zagreb 2004.

Matvejević P., Brewiarz śródziemnomorski, przeł. D. Cirlić-Straszyńska, Pogranicze, Sejny 2003.

Matvejević P., Mediteranski brevijar, Grafički zavod Hrvatske, Zagreb 1990.

Novak S., Dziennik pozapokładowy, przeł. D. Cirlić-Straszyńska, Państwowy Instytut Wydawniczy, Warszawa 1979.

Novak S., Izvanbrodski dnevnik (tri putovanja), Studentski centar sveučilišta u Zagrebu, Zagreb 1976.

Orhel N., Alarm na oddziale onkologii, przeł. W. Romanowski, „Agawa”, Warszawa 1999.

Orhel N., Uzbuna na odjelu za rak, Znanje, Zagreb 1990.

Sajko I., Rio bar, Stubovi kulture, Beograd 2011.

Sajko I., Rio Bar, przeł. D. Jovanka Ćirlić, Wydawnictwo W.A.B., Warszawa 2011.

Slamnig I., Bolja polovica hrabrosti, Večernji list, Zagreb 2004.

Slamnig I., Lepsza połowa odwagi, przeł. A. Dukanović, Państwowy Instytut Wydawniczy, Warszawa 1976.

Šoljan A., Luka, Znanje, Zagreb 1974.

Šoljan A., Port, przeł. M. Krukowska, Państwowy Instytut Wydawniczy, Warszawa 1981.

Špoljar K., Czas i pajęczyna, przeł. H. Kirchner, Wydawnictwo Literackie, Kraków 1987.

Špoljar K., Kłopoty z muza, przeł. D. Cirlić-Straszyńska, Wydawnictwo Łódzkie, Łódź 1983.

Špoljar K., Neprilike s muzom, Razlog, Zagreb 1976.

Špoljar K., Ślub w Paryżu, przeł. D. Cirlić-Straszyńska, Państwowy Instytut Wydawniczy, Warszawa 1990.

Špoljar K., Vjenčanje u Parizu, Matica hrvatska, Zagreb 1980.

Špoljar K., Vrijeme i paučina: sentimentalni odgoj na hrvatski način, Matica hrvatska, Zagreb 1971.

Ugrešić D., Nikog nema doma, Fabrika knjiga, Beograd 2005.

Ugrešić D., Nikogo nie ma w domu, przeł. D. Jovanka Ćirlić, Wydawnictwo Znak, Kraków 2008.

\section{Literatura}

Anić V., Rječnik hrvatskog jezika, Novi Liber, Zagreb 1998.

Babić S., Finka B., Moguš M., Hrvatski pravopis, Školska knjiga, Zagreb 1994.

Barić E. et al., Hrvatska gramatika, Školska knjiga, Zagreb 1997.

Belaj B., Tanacković-Faletar G., Kognitivna gramatika hrvatskoga jezika. Knjiga prva: Imenska sintagma i sintaksa padeža, Disput, Zagreb 2014.

Dunaj B., Wspótczesny słownik języka polskiego, Langenscheidt, Warszawa 2007, CD-ROM.

Frančić A., Mihaljević M., Hudeček L., Normativnost i višefunkcionalnost u hrvatskome standardnom jeziku, Hrvatska sveučilišna naklada, Zagreb 2005.

Grochowski M., O strukturze semantycznej przyzwolenia, [w:] Semantyka tekstu i języka, red. R. Mayenowa, Zakład Narodowy im. Ossolińskich, Wrocław 1976.

Jonke L., Književni jezik u teoriji i praksi, Znanje, Zagreb 1965.

Klemensiewicz Z., Zarys sktadni polskiej, PWN, Warszawa 1953.

Lesz-Duk M., Przyimki wtórne w języku polskim, Wydawnictwo Akademii im. Jana Długosza, Częstochowa 2011.

Maretić T., Gramatika i stilistika hrvatskoga ili srpskoga književnog jezika, L. Hartman, Zagreb 1899. 
Milewska B., Przyimki wtórne we wspótczesnej polszczyźnie, Wydawnictwo Uniwersytetu Gdańskiego, Gdańsk 2003.

Milewska B., Stownik polskich przyimków wtórnych, Wydawnictwo Uniwersytetu Gdańskiego, Gdańsk 2003.

Opačić N., Reci mi to kratko i jasno, Novi Liber, Zagreb 2009.

Pavešić S., Barac-Grum V., Jezični savjetnik s gramatikom, Matica hrvatska, Zagreb 1971.

Raguž D., Praktična hrvatska gramatika, Medicinska naklada, Zagreb 1997.

Rječnik hrvatskoga jezika, red. J. Šonje, Leksikografski zavod „Miroslav Krleža” — Školska knjiga, Zagreb 2000.

Silić J., Pranjković I., Gramatika hrvatskoga jezika, Školska knjiga, Zagreb 2007.

Topolińska Z., Składnia grupy imiennej, [w:] Gramatyka współczesnego języka polskiego. Składnia, red. Z. Topolińska, PWN, Warszawa [1984].

Uniwersalny słownik języka polskiego, PWN, Warszawa 2004, CD-ROM.

\section{Źródła internetowe}

Hrvatski jezični portal, http://hjp.znanje.hr.

Rišner V., Unatoč tome, tomu i toga, http://radio.hrt.hr/ep/unatoc-tome-tomu-i-toga/142292/.

\section{Polish equivalents of Croatian preposition unatoč}

\section{Summary}

This paper provides an analysis of Polish translation equivalents of Croatian preposition unatoč. Based on the corpus of modern Croatian prose translated into Polish we establish that unatoc can be translated by secondary prepositions mimo, względem, pomimo, na przekór, collocation nie zwracajac uwagi na, and concessive clause introduced by the conjunction choć, chociaż. The main equivalent - mimo was established on the basis of frequency and semantic features.

Keywords: translation, equivalence, preposition, Croatian language, Polish language, contrastive linguistics

\section{Poljski ekvivalenti hrvatskoga prijedloga unatoč}

Rezime

U ovom se članku vrši analiza poljskih prijevodnih ekvivalenata hrvatskog prijedloga unatoč. Oslanajući se na korpus hrvatske suvremene proze i njenih poljskih prijevoda zaključujemo da prijed$\log$ unatoč može biti preveden četirima sekundarnim prijedlozima mimo, względem, pomimo, na przekór, kolokacijom nie zwracając uwagi na i adverbijalnom dopusnom rečenicom uvedenom veznicima choć, chociaż. Glavni ekvivalent: mimo je utvrđen na temelju čestoće i semantičnih osobina.

Ključne riječi: prijevod, ekvivalencija, prijedlog, hrvatski jezik, poljski jezik, kontrastivna lingvistika 